\title{
Penerapan Metode Naive Bayes dalam Menentukan Pengaruh Penasihat Akademik pada Kelulusan Mahasiswa Tingkat Akhir
}

\author{
Sakila Wulandari' ${ }^{1}$ Poningsih ${ }^{2}$, Widodo Saputra ${ }^{3}$ \\ ${ }^{1}$ STIKOM Tunas Bangsa Pematangsiantar \\ ${ }^{2}$ AMIK Tunas Bangsa Pematangsiantar \\ Jl.Jenderal Sudirman Blok A No.1/2/3 Pematangsiantar,Medan,Indonesia,21127 \\ sakilawulandari@gmal.com ${ }^{1}$, poningsih@amiktunasbangsa.ac.id ${ }^{2}$ \\ widodosaputra@amiktunasbangsa.ac.id ${ }^{3}$
}

\begin{abstract}
In the lecture there is a permanent lecturer who serves as an Academic Adviser namely a person whose job is to provide students with assistance in adjusting to lectures and assisting students in solving problems encountered during college by providing various alternatives for students. Students are required to have abilities and expertise. To achieve the objectives of final year students and also universities in graduating the best graduates, communication between students and lecturers is needed. Because it is very influential in training mentally students and is very helpful for students in completing their lectures. The influence of an academic advisor can actually be an important factor for final year students, but students may also consider it to have no effect on their graduation. So the Naive Bayes method, in order to find out whether Academic Advisers play an important role in the graduation of final year students, students are asked to fill out a questionnaire relating to the influence or not of the Academic Advisor on final graduation. It is hoped that this study can determine the effect or absence of Academic Advisers on the graduation of final year students, later the results of the output from this system can be an evaluation material for universities.
\end{abstract}

Keywords: Students, Academic Advisor, Datamining, Naive Bayes

\begin{abstract}
Abstrak - Didalam perkuliahan ada seorang dosen tetap yang menjabat sebagai Penasihat Akademik yaitu orang yang tugasnya memberikan mahasiswa bantuan dalam menyesuaikan diri didalam perkuliahan dan membantu mahasiswa dalam memecahkan masalah yang dihadapi selama berkuliah dengan cara memberi berbagai alternatif untuk mahasiswa. Mahasiswa dituntut untuk memiliki kemampuan dan keahlian. Untuk mencapai tujuan dari mahasiswa tingkat akhir dan juga perguruan tinggi dalam meluluskan lulusan terbaik maka komunikasi antara mahasiwa dan dosen sangat diperlukan. Karena hal tersebut sangat berpengaruh dalam melatih mental mahasiswa dan sangat membantu mahasiswa dalam menyelesaikan perkuliahan nya. Pengaruh penasihat akademik sebenarnya bisa menjadi faktor yang penting untuk mahasiswa tingkat akhir, tetapi bisa juga mahasiswa menganggap nya tidak berpengaruh terhadap kelulusan mereka. Maka metode Naive bayes ini, agar dapat mengetahui apakah Penasihat Akademik berperan penting terhadap kelulusan mahasiswa tingkat akhir, mahasiswa diminta untuk mengisi kuesioner berkaitan dengan berpengaruh atau tidak nya Penasihat Akademik terhadap kelulusan mahasiswa tingkat akhir. Diharapkan penelitian ini dapat mengetahui pengaruh atau tidaknya Penasihat Akademik terhadap kelulusan mahasiswa tingkat akhir, nantinya hasil ouput dari sistem ini dapat menjadi bahan evaluasi untuk perguruan tinggi.
\end{abstract}

Kata kunci : Mahasiswa, Penasihat Akademik, Data mining, Naive Bayes 


\section{PENDAHULUAN}

Naive Bayes adalah sebuah pengklasifikasian probabilistik sederhana yang menghitung sekumpulan probabilitas dengan menjumlahkan frekuensi dan kombinasi nilai dari dataset yang diberikan [1]. Algoritma mengunakan teorema Bayes dan mengasumsikan semua atribut independen atau tidak saling ketergantungan yang diberikan oleh nilai pada variabel kelas[2]. Berdasarkan penjelasan tersebut, ada beberapa penelitian yang dimana memiliki penyelesaian dengan menggunakan metode Nä̈ve Bayes yang telah dilakukan salah satunya oleh :[3]. Berdasarkan hasil penelitian tentang Klasifikasi Tingkat Kemungkinan Obesitas Mahasiswa Sistem Informasi UIN Suska Riau, dalam pembahasan yang telah dilakukan dapat disimpulkan bahwa algoritma Nä̈ve Bayes Classification yang dimana hasil pengujian menunjukkan dengan akurasi sebesar $66,67 \%$ yaitu 16 responden beresiko untuk mendapatkan kemungkinan obesitas tingkat sedang. 69 responden mempunyai tingkat gizi normal, 3 responden mempunyai kekurangan gizi.

\section{Metode Penelitian}

Metode Penelitian berisikan cara ilmiah untuk mengumpulkan data, menganalisa data, lokasi dan waktu dalam pengumpulan data dengan tujuan dan kegunaan tertentu. Penelitian ini di aplikasikan dengan menggunakan data mining dalam mengklasifikasikan pengaruh penasihat akademik terhadap mahasiswa tingkat akhir. Adapun metode yang digunakan dalam penelitian ini adalah metode naive bayes.

\subsection{Metode Pengumpulan Data}

Pengumpulan data yang digunakan untuk penelitian ini terdiri dari :

1. Observasi

Penulis melakukan pengamatan langsung terhadap mahasiswa tingkat akhir di STIKOM Tunas Bangsa Pematangsiantar baik mahasiswa Prodi Sistem Informasi atau Teknik Informatika stambuk 2015 yang sedang menyusun skripsi sebagai syarat kelulusan.

2. Kuesioner

Yaitu proses pengumpulan data atau informasi dengan cara memberikan sebuah pertanyaan atau pernyatan kepada orang lain. Penulis memberikan kuesioner kepada mahasiswa STIKOM Tunas Bangsa Pematangsiantar mengenai pertanyaan yang berhubungan dengan pengaruh penasihat akademik terhadap kelulusan mahasiswa tingkat akhir dengan menggunakan linker 5 yaitu SS, S, N, TS, STS. 
Kuesioner yang digunakan dalam penelitian ini adalah :

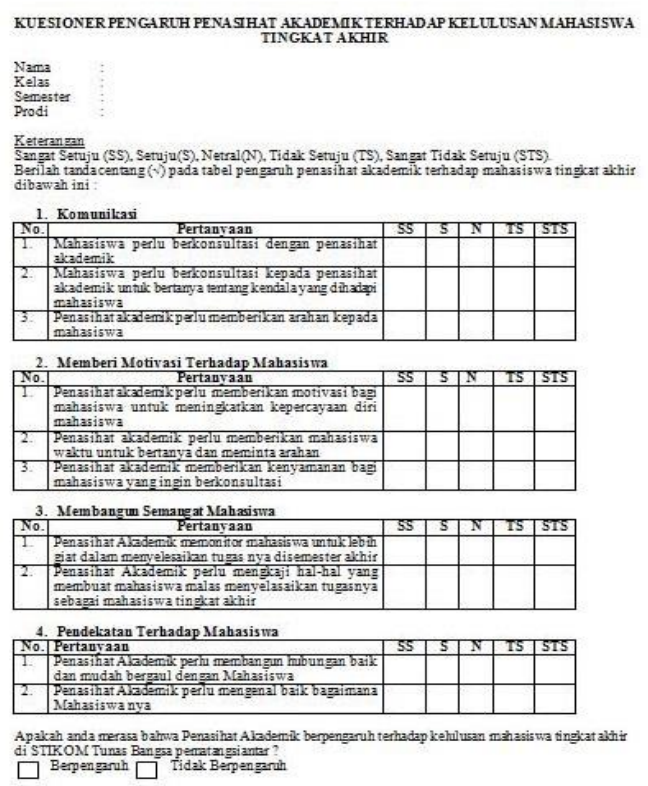

Gambar 1. Kuesioner Pengaruh Penasihat Akademik Terhadap Kelulusan Mahasiwa Tingkat Akhir

1. Studi Pustaka

Tahapan ini penulis mengumpulkan data, mempelajari data, dan mencari referensi terkait dengan kasus pada penelitian dengan cara browsing ke internet. Hasil luaran dari studi literatur ini adalah tersusun dan terkoleksinya referensi yang baik dan benar dengan penelitian.

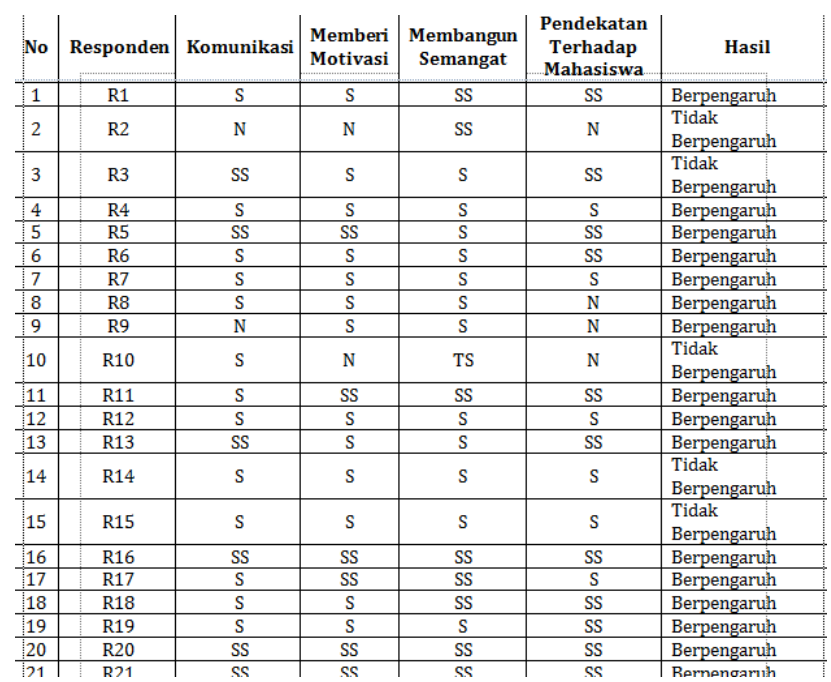

Tabel 2. Data yang dikumpulkan 
Metode analisis data terdiri atas dua macam, yaitu metode statistik deskriptif dan metode statistik inferensial. Jika pada metode penelitian penulis menggunakan metode penelitian kuantitatif, maka metode analisa data yang penulis gunakan adalah metode statistik inferensial. Data yang digunakan terdiri dari 4 parameter yaitu:

a.Komunikasi

b.Memberi Motivasi Terhadap Mahasiswa

c.Membangun Semangat Mahasiswa

d.Pendekatan Terhadap Mahasiswa

Setiap faktor terdiri beberapa isi berupa pertanyaan yang diajukan ke mahasiswa STIKOM Tunas Bangsa Pematangsiantar. Pertanyaan yang digunakan selanjutnya mencari rata-rata dari faktor yang digunakan. Data yang digunakan menggunakan kuesioner yang diberikan kepada mahasiswa STIKOM Tunas Bangsa. Kuesioner yang diberikan menggunakan linker 5 yang terdiri dari $S$ (Setuju), SS (Sangat setuju), N (Netral), TS (Tidak Setuju), STS (Sangat Tidak Setuju) . Hasil dari kuesioner kemudian data akan diolah menggunakan metode naïve bayes dan akan di uji ke RapidMiner.

\subsection{Data Mining}

Data Mining adalah proses yang menggunakan teknik statistik, matematika, kecerdasan buatan, machine learning untuk mengekstraksi dan mengidentifikasi informasi yang bermanfaat dan pengetahuan yang terkait dari berbagai database besar. Data mining disebut juga dengan knowledge discovery in database (KDD) ataupun pattern recognition [4]-[7]. Data Mining dapat dibagi menjadi empat kelompok, yaitu model prediksi (prediction modelling), analisis kelompok (Cluster analysis), analisis asosiasi (association analysis) dan deteksi anomaly (anomaly detection)[8].

\subsection{Naive Bayes}

Algoritma mengunakan teorema Bayes dan mengasumsikan semua atribut independen atau tidak saling ketergantungan yang diberikan oleh nilai pada variabel kelas. Definisi lain mengatakan Naive Bayes merupakan pengklasifikasian dengan metode probabilitas dan statistik yang dikemukan oleh ilmuwan Inggris Thomas Bayes, yaitu memprediksi peluang di masa depan berdasarkan pengalaman di masa sebelumnya. Naive Bayes didasarkan pada asumsi penyederhanaan bahwa nilai atribut secara kondisional saling bebas jika diberikan nilai output. Dengan kata lain, diberikan nilai output, probabilitas mengamati secara bersama adalah produk dari probabilitas individu[9].

\subsection{Klasifikasi}

Klasifikasi adalah proses untuk menemukan model atau fungsi yang menjelaskan atau membedakan konsep atau kelas data, dengan tujuan untuk dapat memperkirakan kelas dari suatu objek yang labelnya tidak diketahui. Dalam mencapai tujuan tersebut, proses klasifikasi membentuk suatu model yang mampu membedakan data kedalam kelas-kelas yang berbeda berdasarkan aturan atau 
fungsi tertentu. Model itu sendiri bisa berupa aturan "jika-maka", berupa pohon keputusan atau formula matematis[10].

\section{Hasil Dan Pembahasan}

Hasil dan pembahasan pada bab ini disajikan sesuai penelitian yang dilakukan. Data yang digunakan dalam penelitian ini adalah data mahasiswa yang menjawab pertanyaan berdasarkan kuesioner yang telah diberikan. Perangkat lunak yang digunakan yaitu rapidmminer 5.3 untuk menyajikan klasifikasi pengaruh penasihat akademik. Data set yang ada terdiri dari kriteria yang di tentukan yaitu komunikasi, memberi motivasi terhadap mahasiswa, membangun semangat mahasiswa dan pendekatan terhadap mahasiswa. Data yang telah didapatkan ditransformasikan ke format data excel 2010. Kumpulan data yang diperoleh digunakan sebagai data masukan dalam membuat model aturan menggunakan algoritma Naive Bayes menggunakan software rapidminer. Dalam mengetahui berpengaruh dan tidak berpengaruh nya penasihat akademik dalam kelulusan mahasiswa tingkat akhir di STIKOM Tunas Bangsa Pematangsiantar, penulis akan menampilkan gambaran model aturan dalam mengklasifikasi pengaruh penasihat akademik terhadap mahasiswa tingkat akhir menggunakan algoritma Naive Bayes.

\subsection{Dataset Penelitian}

Metode Naive Bayes digunakan dalam pemodelan data yang akan ditampilkan. Data didapatkan dengan memberikan kuesioner kepada mahasiswa untuk mengetahui apakah penasihat akademik berpengaruh bagi mereka yag sedang menjalani tingkat akhir. Data yang akan diolah ada data training dan data testing. Data training yang digunakan terdapat 98 data sedangkan data testing terdapat 2 data yang digunakan. Kriteria data yang telah ditentukan dianalisis menggunakan perangkat lunak rapidminer 5.3. data Kuesioner yang akan dianalisis memiliki 100 data.

\subsection{Masukan (Input) Sistem}

Dalam menjalankan proses dalam membentuk model aturan, terlebih dahulu importing data dari data yang sudah di transformasi terlebih dahulu ke dalam microsoft word excel dan diakses menggunakan software Rapidminer. Atribut yang digunakan sebagai label adalah hasil dari kuesioner pengaruh penasehat akademik menggunakan data yang telah dipilih yaitu data kuesioner. Dalam melakukan importing data, dibutuhkan operator data kuesioner seperti gambar berikut. 


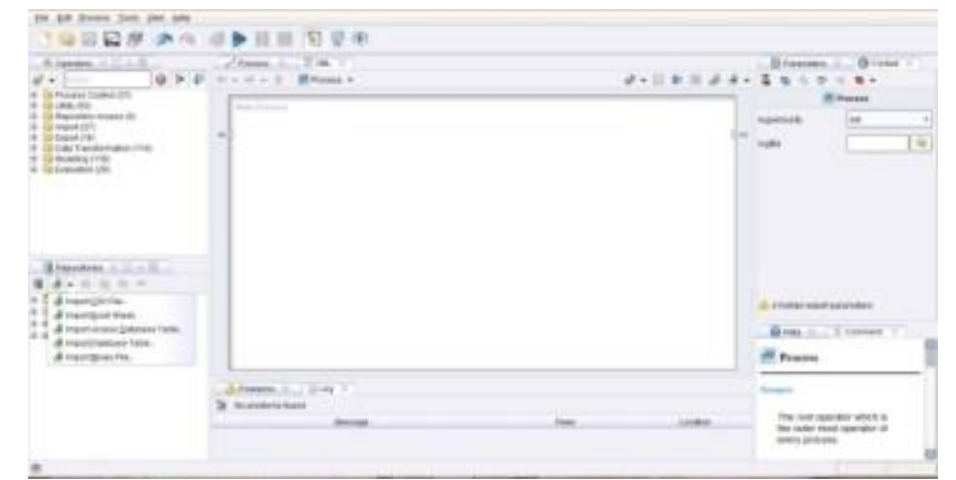

Gambar 3. New Process untuk Import Data Excel

\subsection{Pemrosesan (Proses) Sistem}

Pilih data yang akan digunakan untuk di import. Lakukan drag and drop data yang dipilih kedalam view process. Berikut alur proses import data yang dilakukan.

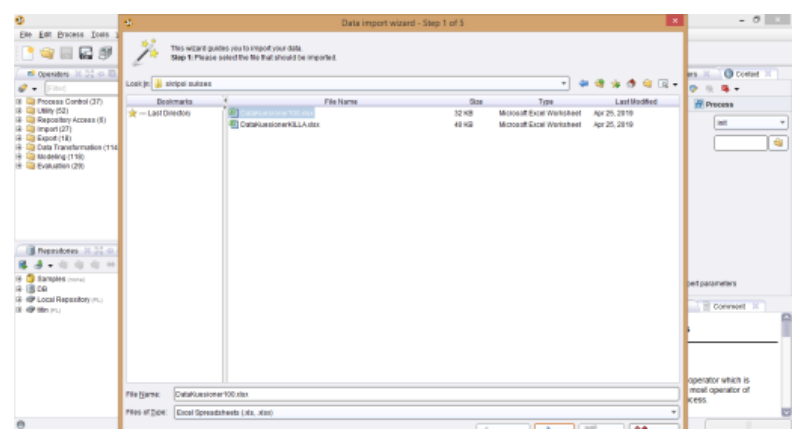

Gambar 4. Alur Proses Import Data Step 1

Pada import data wizard step 1, pilih data berformat .csv pada folder yang akan di import.

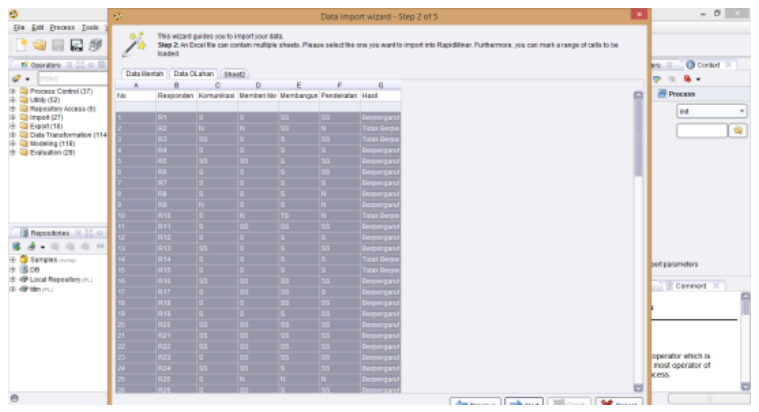

Gambar 5. Alur Proses Import Data Step 2

\subsection{Keluaran (Output) Sistem}

Pada saat alur import data selesai, maka selanjutnya drag and drop kedalam main process. Didalam main process akan memvalidasikan data yang dimodelkan kedalam algoritma dan fungsi validation ini adalah memaksimalkan nilai akurasi pengolahan data. 


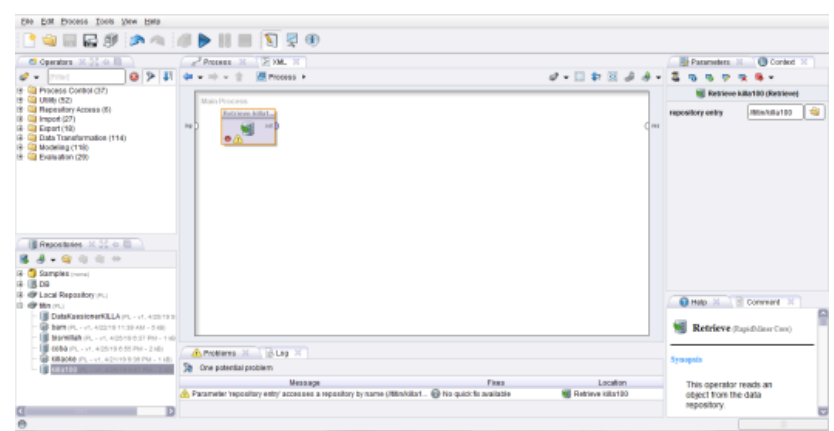

Gambar 6. Drag and Drop Data Kuesioner

Langkah berikutnya drag dan drop operator Naive Bayes lalu hubungkan pada output.

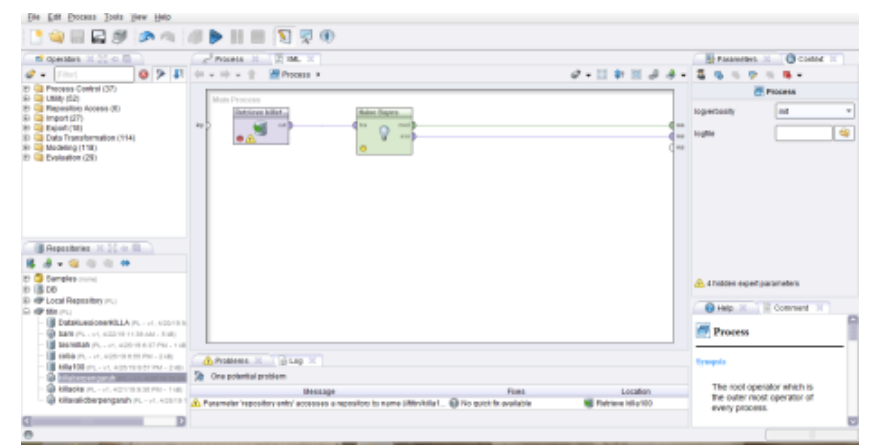

Gambar 7. Drag dan Drop Operator Naive Bayes

Pada saat tool run diklik akan muncul pohon keputusan seperti gambar dibawah.

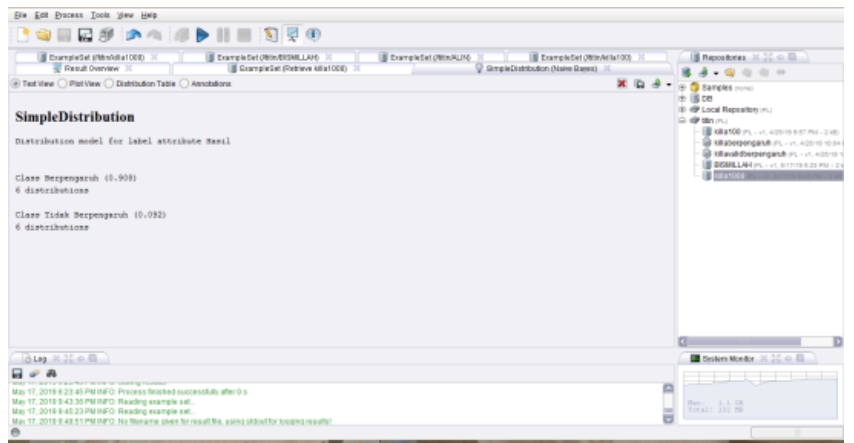

Gambar 8. Data Hasil Klasifikasi

Berdasarkan gambarn 8. menjelaskan bahwa kelas Tidak Berpengaruh memiliki nilai klasifikasi/probabilitas 0,092 sedangkan kelas Berpengaruh mendapatkan nilai klasifikasi/probabilitas 0,908.

Sehingga berdasarkan data hasil klasifikasi pada gambar 4.9 didapatkan grafik hasil dari rapidminer 5.3 berikut ini : 


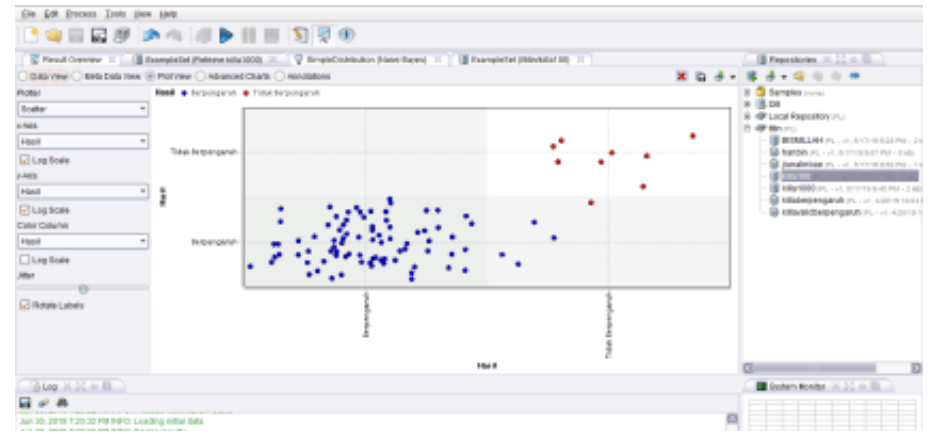

Gambar 9. Grafik klasifikasi

Berdasarkan pada gambar 9. dapat diketahui bahwa pada titik berwarna biru (berpengaruh) memiliki banyak node yaitu 89, sedangkan pada titik berwarna biru (Tidak Puas) memiliki hanya 9 node.

\section{Kesimpulan}

Berdasarkan hasil dari penelitian ini, dapat disimpulkan beberapa hal mengenai Penerapan Metode Naive Bayes dalam Menentukan Pengaruh Penasihat Akademik Terhadap Kelulusan Mahasiswa Tingkat Akhir yaitu Nä̈ve Bayes dapat diterapkan untuk mencari Pengaruh Penasihat Akademik dengan cara membandingkan nilai berpengaruh dan tidak berpengaruh dengan melihat nilai terbesar dari nilai yang didapatkan. Hasil yang didapatkan adalah kelas Tidak Berpengaruh memiliki nilai klasifikasi/probabilitas 0,090 sedangkan kelas Berpengaruh mendapatkan nilai klasifikasi/probabilitas 0,910. Maka dapat disimpulkan bahwa Mahasiswa memerlukan Penasihat Akademik untuk membantu mereka dalam menghadapi beragam masalah yang bisa saja muncul ketika mereka sedang menyelesaikan perkuliahan mereka.

\section{DAFTRA PUSTAKA}

[1] S. Haryati, A. Sudarsono, and E. Suryana, "Implementasi Data Mining untuk Memprediksi Masa Studi Mahasiswa Menggunakan Algoritma C4.5," Jurnal Media Infotama, vol. 11, no. 2, pp. 130-138, 2015.

[2] J. Anidar, "Peran penasehat akademik terhadap kesuksesan mahasiswa di perguruan tinggi," pp. 216-224.

[3] F. Kiki and A. P. Windarto, "DATA MINING : PENERAPAN RAPIDMINER DENGAN K-MEANS CLUSTER PADA DAERAH TERJANGKIT DEMAM BERDARAH DENGUE ( DBD ) BERDASARKAN PROVINSI," vol. 3, no. 2, pp. 173-178, 2018.

[4] I. Parlina, A. P. Windarto, A. Wanto, and M. R. Lubis, "Memanfaatkan Algoritma K-Means dalam Menentukan Pegawai yang Layak Mengikuti Asessment Center untuk Clustering Program SDP," CESS (Journal of Computer Engineering System and Science), vol. 3, no. 1, pp. 87-93, 2018.

[5] S. Sudirman, A. P. Windarto, and A. Wanto, "Data Mining Tools | RapidMiner: K-Means Method on Clustering of Rice Crops by Province as Efforts to Stabilize Food Crops In Indonesia," IOP Conference Series: Materials Science and Engineering, vol. 420, no. 12089, pp. 1-8, 2018.

[6] R. W. Sari, A. Wanto, and A. P. Windarto, "Implementasi Rapidminer dengan Metode KMeans (Study Kasus: Imunisasi Campak pada Balita Berdasarkan Provinsi)," KOMIK (Konferensi Nasional Teknologi Informasi dan Komputer), vol. 2, no. 1, pp. 224-230, 2018.

[7] M. G. Sadewo, A. P. Windarto, and A. Wanto, "Penerapan Algoritma Clustering dalam 
Mengelompokkan Banyaknya Desa/Kelurahan Menurut Upaya Antisipasi/ Mitigasi Bencana Alam Menurut Provinsi dengan K-Means," KOMIK (Konferensi Nasional Teknologi Informasi dan Komputer), vol. 2, no. 1, pp. 311-319, 2018.

[8] E. Manalu and F. A. S. M. R. Manalu, "PENERAPAN ALGORITMA NAIVE BAYES UNTUK MEMPREDIKSI JUMLAH PRODUKSI BARANG BERDASARKAN DATA PERSEDIAAN DAN JUMLAH PEMESANAN PADA CV . PAPADAN MAMA PASTRIES," Jurnal Mantik Penusa, vol. 1, no. 2, 2017.

[9] A. N. Putri, "PENERAPAN NAIVE BAYESIAN UNTUK PERANKINGAN KEGIATAN DI FAKULTAS TIK UNIVERSITAS SEMARANG,” Jurnal SIMETRIS, vol. 8, no. 2, pp. 603-610, 2017.

[10] Y. N. Kunang and S. Murniati, "IMPLEMENTASI TEKNIK DATA MINING UNTUK MEMPREDIKSI TINGKAT KELULUSAN MAHASISWA PADA UNIVERSITAS BINA," Seminar Nasional Informatika 2013, vol. 2013, no. semnasIF, pp. 56-63, 2013. 